\title{
Key Plant, Key Pests: Sycamore (Platanus spp.) ${ }^{1}$
}

\author{
Matthew Borden, Kelly Laplante, Juanita Popenoe, Adam Dale, Caroline R. Warwick, and Brian \\ Pearson ${ }^{2}$
}

\section{Key Plant: Sycamore (Platanus spp.)}

The American sycamore (Platanus occidentalis) is an iconic species native to the eastern half of the United States, USDA hardiness zones $4 \mathrm{~B}$ to $9 \mathrm{~A}$. The tree grows rapidly up to 75-100 ft tall with a 50-70 ft wide crown at maturity. The species is best enjoyed as a striking specimen tree or in its native environment of low-lying areas and along waterways. American sycamore should be planted with caution and forethought in urban settings because it can quickly outgrow smaller spaces and may be considered a nuisance due to shedding bark, dropping large seedpods, and shedding enormous leaves (up to 9 inches wide) in autumn. American sycamore is long-lived and may exceed 250 years in the wild, but it often develops wood rot in old age, and falling limbs can be a concern. Crowns are pyramidal during early growth stages, maturing to a more rounded shape to create a dense and symmetrical canopy. A particularly ornamental trait is the naturally peeling bark of the massive trunk and branches, creating a patchwork pattern of white, tan, reddish-brown, and even green bark.

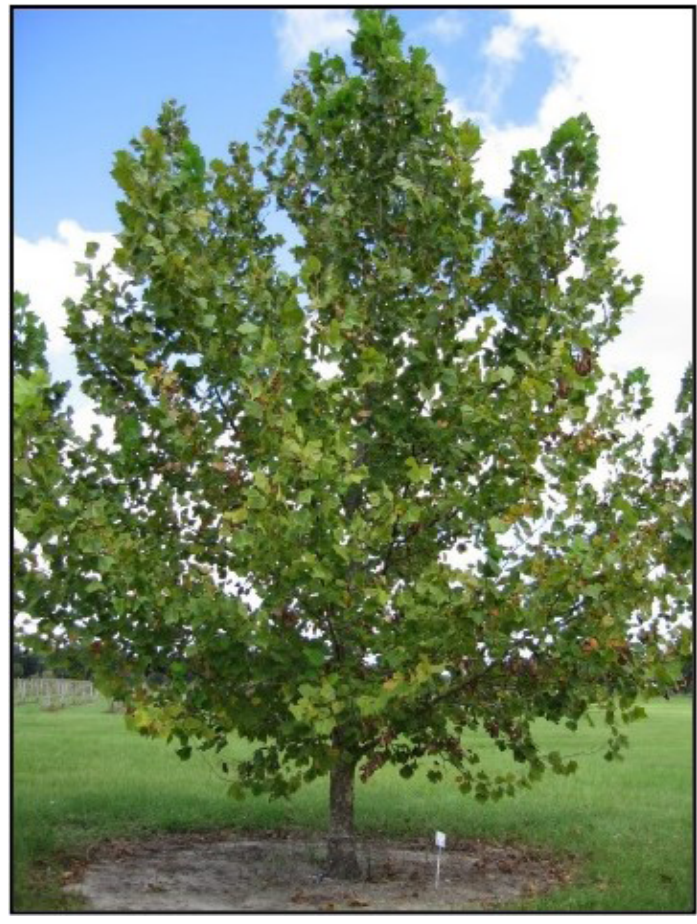

Figure 1. A sycamore tree. Credits: Juanita Popenoe, UF/IFAS

London planetree is a widely planted and historically significant hybrid cross of Platanus orientalis $\times$ Platanus occidentalis (better known as Platanus $\times$ acerifolia). Several selections offering improved disease resistance are available,

1. This document is ENH1337, one of a series of the Environmental Horticulture Department, UF/IFAS Extension. Original publication date March 2021. Visit the EDIS website at https://edis.ifas.ufl.edu for the currently supported version of this publication.

2. Matthew Borden, graduate research assistant, Doctor of Plant Medicine program; Kelly Laplante, undergraduate research assistant, Entomology and Nematology Department; Juanita Popenoe, multicounty commercial fruit production agent IV, UF/IFAS Extension Lake County, Tavares, FL; Adam Dale, assistant professor, Entomology and Nematology Department; Caroline R. Warwick, science communication specialist; and Brian Pearson, assistant professor, Environmental Horticulture Department, UF/IFAS Extension, Mid-Florida Research and Education Center, Apopka, FL 32703.

Use pesticides safely. Read and follow directions on the manufacturer's label.

The Institute of Food and Agricultural Sciences (IFAS) is an Equal Opportunity Institution authorized to provide research, educational information and other services only to individuals and institutions that function with non-discrimination with respect to race, creed, color, religion, age, disability, sex, sexual orientation, marital status, national origin, political opinions or affiliations. For more information on obtaining other UF/IFAS Extension publications, contact your county's UF/IFAS Extension office. U.S. Department of Agriculture, UF/IFAS Extension Service, University of Florida, IFAS, Florida A \& M University Cooperative Extension Program, and Boards of County Commissioners Cooperating. Nick T. Place, dean for UF/IFAS Extension. 
including 'Bloodgood' and 'Liberty'. Both hybrids can grow to be $85 \mathrm{ft}$ tall, with a crown width of $70 \mathrm{ft}$, maturing to a similar rounded crown shape as the American sycamore. London planetree grows best in USDA hardiness zones 5-8. While they can be grown in zone 9 (central Florida), they are unlikely to thrive. The attractive bark of the hybrids is similar to the bark on the American sycamore, containing different hues of olive green, $\tan$, white, and brown. The large 4-12 inch leaves are considered a nuisance when they fall due to their size and prevalence. One way to distinguish American sycamore from London planetree is that American sycamore leaves have lower lobes that curve strongly downward toward the branch, while London planetree leaves have a flatter base, roughly perpendicular to the petiole.

Other notable Platanus species include Rzedowski's sycamore (Platanus rzedowskii) and Oriental planetree (Platanus orientalis). Neither is native to or commonly planted in the United States, but they can grow in USDA hardiness zones $8 \mathrm{~B}$ or warmer and $7 \mathrm{~A}$ to $9 \mathrm{~A}$, respectively. Both can make attractive ornamental specimen plantings.

Sycamore species, especially London planetree, are often used in urban areas for shade along sidewalks, roads, and parking lots. Sycamores are known for their tolerance to a wide range of poor soil conditions, such as low oxygen, compacted soils, or high $\mathrm{pH}$, making them attractive choices for urban sites. However, their large leaves and seedpods are considered messy. It is recommended to plant all species at least $12 \mathrm{ft}$ away from the nearest pavement or structures due to their aggressive root growth. Ideally, Platanus spp. should be planted in areas with adequate soil moisture and root space, allowing them to grow healthily to their full size.

\section{Key Pests: Platanus spp.}

This series of Key Plant, Key Pests publications is designed for Florida gardeners, horticulturalists, and landscape professionals to help identify common pests associated with regional flora. This publication helps identify the most common pests found on trees in the sycamore group, Platanus spp.

This publication provides information and general management recommendations for sycamore lace bug, bacterial leaf scorch, powdery mildew, anthracnose, and canker-stain. For a more comprehensive guide of woody ornamental insect management, download the current Professional Disease Management Guide for Ornamental Plants or the Integrated Pest Management in the Commercial Ornamental Nursery guide.

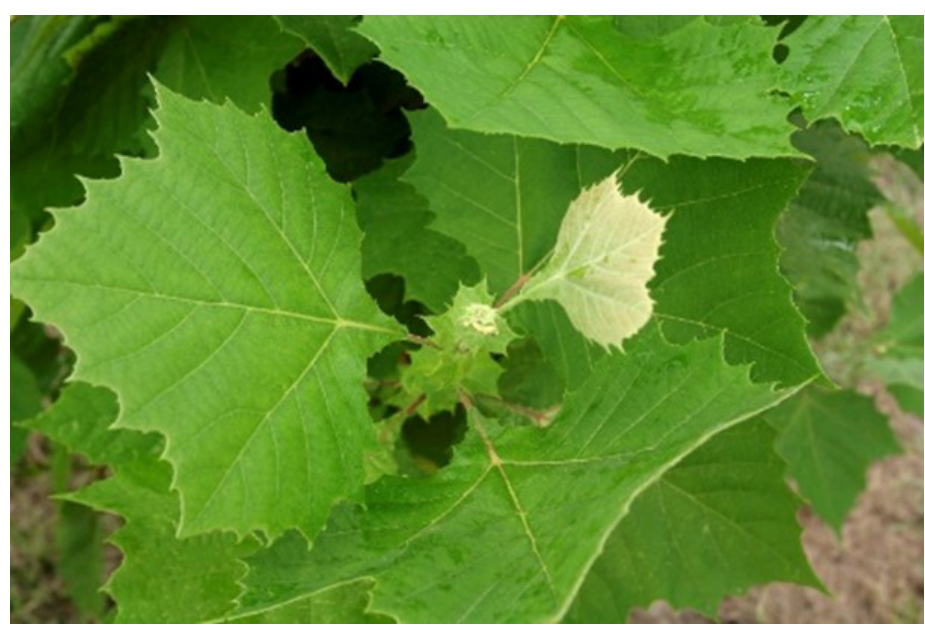

Figure 2. Healthy sycamore leaves. Credits: Thomas Wright, UF/IFAS

\section{Sycamore Lace Bug, Corythucha ciliata (Say)}

\section{SPECIES SUSCEPTIBILITY}

All species of Platanus are susceptible to sycamore lace bugs, but some observations suggest that Rzedowski's sycamore is less prone to severe lace bug damage.

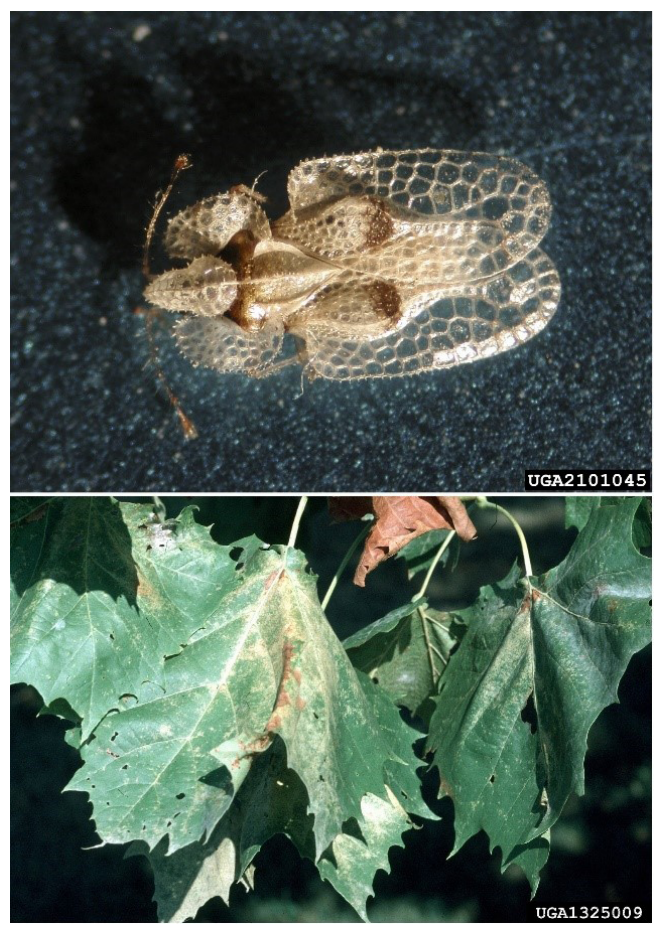

Figure 3. Close-up of an adult sycamore lace bug and damage caused by feeding.

Credits: Louis-Michel Nageleisen, Département de la Santé des Forêts, and Whitney Cranshaw, Colorado State University, Bugwood.org

\section{RECOGNITION}

Damage can be recognized by the pale-white to silvery patches of stippling on the topside of leaves caused by lace bug feeding on the underside. Damage starts near the leaf veins. Damage may later result in yellowing or 
bronzing of foliage in late summer and premature leaf drop. Mature lace bugs are about $1 / 8$ " long and light in color with lace-patterned wings. Sycamore lace bug is the only lace bug known to feed on sycamore. The nymphs are darker colored and wingless. When lace bugs are present, tiny spots of dark-brown to black excrement can be found on the underside of leaves.

\section{CONTRIBUTING FACTORS}

These lace bugs are only a pest of sycamore, but they may occasionally be found on paper mulberry (Broussonetia papyrifera), shagbark hickory (Carya ovata), leather leaf (Champaedaphne spp.), and ash (Fraxinus spp.). There are multiple generations per year in the South, so populations are highest in the late season.

\section{MANAGEMENT RECOMMENDATIONS}

Healthy sycamore trees are able to tolerate annual lace bug infestations in most cases. Because lace bug infestations build up over the season, premature defoliation may not be significantly earlier than normal autumn leaf drop. Chemical control of lace bugs is typically not warranted and may hamper natural predation by assassin bugs, spiders, lacewings, and other important predators and parasites. However, if the cost and environmental risk is deemed necessary, insecticide tree injections have successfully reduced injury (Halbert and Meeker 2017).

\section{Bacterial Leaf Scorch (Xylella fastidiosa) SPECIES SUSCEPTIBILITY}

Rzedowksi's sycamore is the only species resistant to bacterial leaf scorch. All other sycamores are susceptible to bacterial leaf scorch.

\section{RECOGNITION}

Early leaf scorch symptoms are olive-green discoloration of margins or interveinal tissue. Affected leaves turn tan, usually with a reddish-brown band between the tan and remaining green tissue. Leaves turn crispy, becoming cupped and curling upwards, but remain attached to the branches for the remainder of the season. This "scorched" appearance is due to $X$. fastidiosa, a bacterial pathogen that systemically infects the plant, restricting the flow of water through the xylem vascular tissue. Symptoms begin on older leaves and progress toward the branch tip. Large portions of the crown or even the entire tree may be affected, characteristically starting from the bottom upward and the inside of the crown outward. Trees affected by bacterial leaf scorch are more susceptible to opportunistic pathogens and may die after several years of gradual weakening.

\section{CONTRIBUTING FACTORS}

$X$. fastidiosa is transmitted by sap-feeding insects, such as leafhoppers, froghoppers, and spittlebugs, but the most important vectors are a group of leafhoppers known as sharpshooters. Scorch symptoms begin to appear during periods of hot, dry weather when the infected plant is most in need of water reaching the leaves, usually in mid to late summer.

\section{MANAGEMENT RECOMMENDATIONS}

There is no cure for bacterial leaf scorch, although systemic antibiotics applied professionally can temporarily suppress the disease. Proper cultural practices are critical to reduce water stress on infected trees. Minimize moisture stress by mulching the root zone and providing supplemental irrigation during periods of heat and drought. Pruning off individual branches as dieback occurs will not slow the disease but may reduce secondary infections.

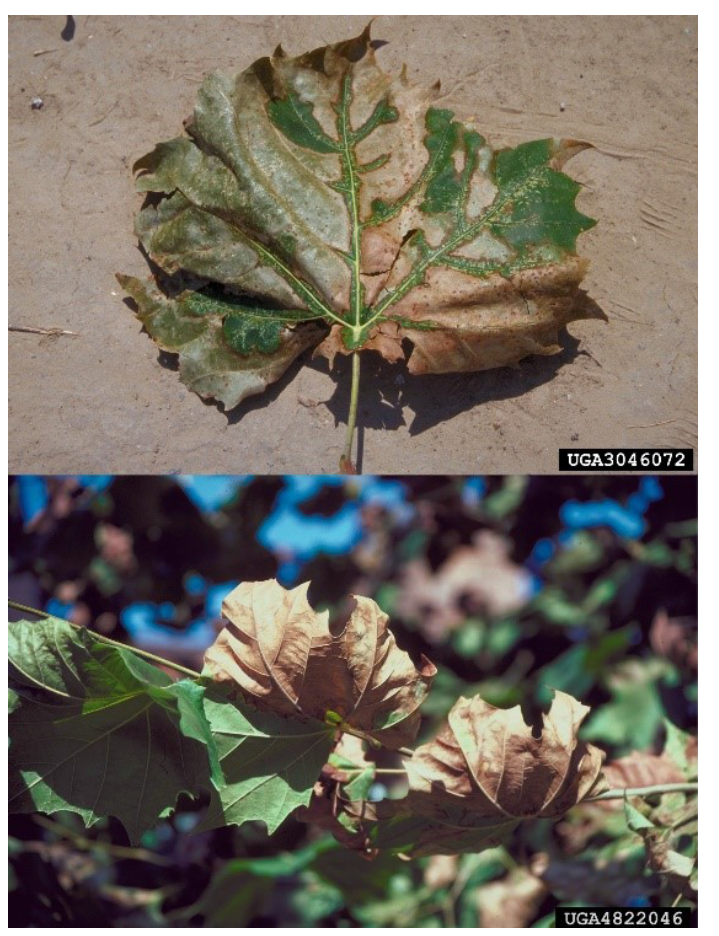

Figure 4. Bacterial leaf scorch symptoms on American sycamore. Note the color transition of green, olive green, and tan, as well as upward curling of scorched leaves.

Credits: (Top) Theodor D. Leininger, USDA Forest Service. (Bottom) Edward L. Barnard, FDACS, Bugwood.org

\section{Powdery Mildew (Erysiphe [=Micosphaera] platani)}

\section{SPECIES SUSCEPTIBILITY}

Rzedowski's sycamore and the London planetree hybrids are more resistant to powdery mildew than the American sycamore, which is highly susceptible. Other sycamore species lie somewhere between these extremes. 


\section{RECOGNITION}

Fungal mycelia appear as characteristic white powdery growth on the upper surface of expanded leaves and all surfaces of emerging leaves and buds. White circles of early infection spots may progress to form patches or cover the entire leaf surface. When young developing tissues are infected, leaf curling, stunting, and distortion may be severe.

\section{CONTRIBUTING FACTORS}

Conidia, the air-blown spores of the fungus, are produced during periods of warm weather when humidity drops. Unlike many other foliar fungal diseases, the spores do not require high humidity or free water to germinate and are inhibited by excessive rain. Cool, relatively dry weather with moderate humidity in spring and fall promotes powdery mildew development.

\section{MANAGEMENT RECOMMENDATIONS}

Approved fungicides for powdery mildew on ornamental trees and shrubs may be used on young trees. They are most effective when applied prior to infection by anticipating environmental conditions favoring disease development. Spraying large trees is not practical and rarely necessary. Proper fertilization is important for disease management, because excessive succulent growth caused by overfertilization is highly susceptible. Lastly, heavy pruning (including pollarding) will produce highly susceptible shoots of new growth.

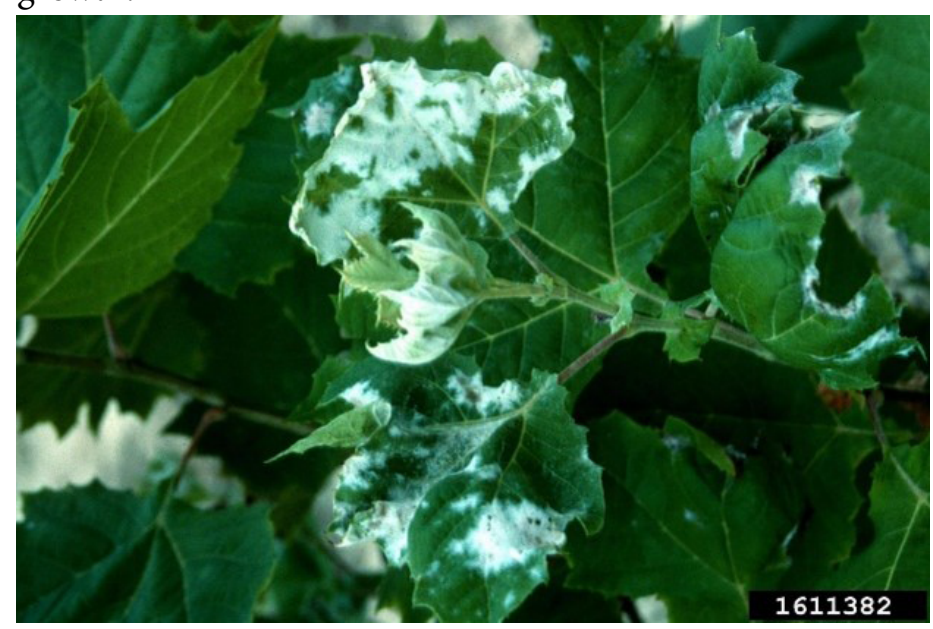

Figure 5. Powdery mildew on a sycamore leaf.

Credits: John Ruter, University of Georgia, Bugwood.org

\section{Canker Stain (Ceratocystis platani) SPECIES SUSCEPTIBILITY}

Canker stain is the most serious disease of sycamores and can cause plant death relatively quickly after infection. All Platanus spp. are susceptible to canker stain. However,
Oriental planetree and the London planetree hybrids sustain more severe damage than American sycamore.

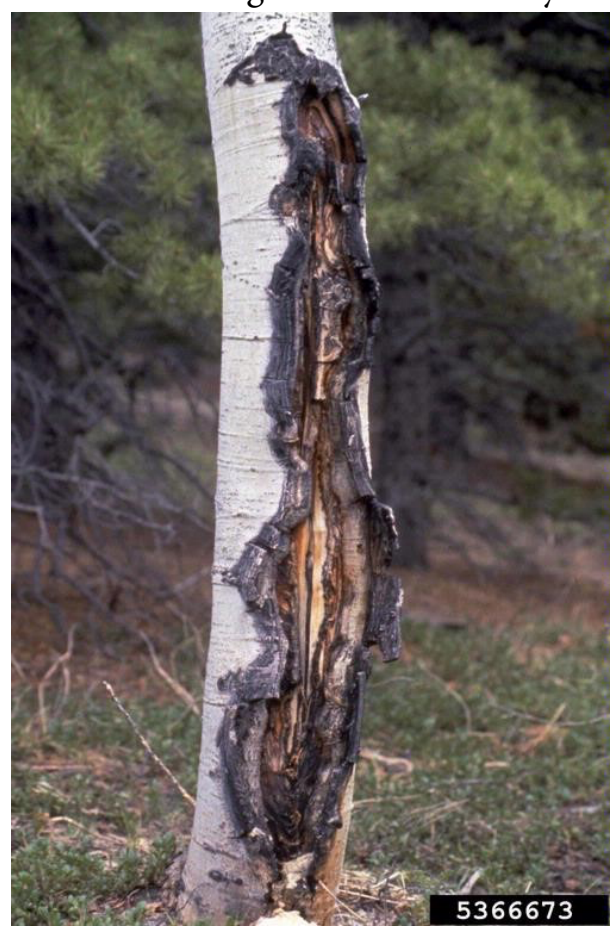

Figure 6. Severe canker stain symptoms.

Credits: Mike Schomaker, Colorado State Forest Service, Bugwood.org

\section{RECOGNITION}

Sycamore canker stain causes the tree canopy to thin as leaves become sparse and smaller branches wilt and die. A closer inspection will reveal elongated sunken cankers on the branches or trunk, and sometimes longitudinal cracking, which may look like an indent or bark injury. Shoots often sprout from the trunk just beneath the canker. Peeling back the bark underneath the canker area will reveal darkpurple to brown spots and staining that extends well above and below the area and slightly to the sides. When cutting through an infected trunk, the stained points may show as spindle-shaped streaks pointing toward the tree center, with mature infections creating a wider wedge shape.

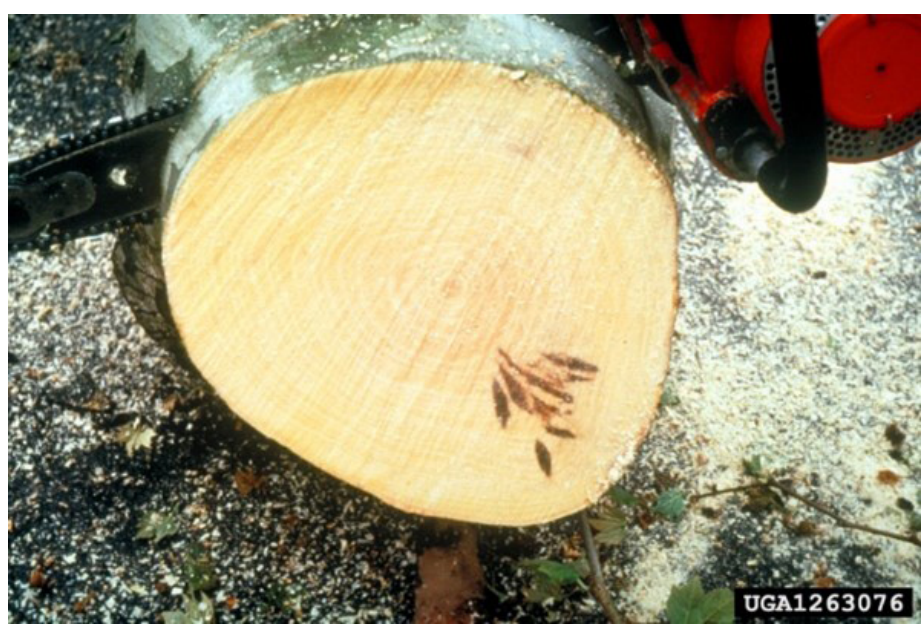

Figure 7. Spindle-shaped staining in the vascular tissue.

Credits: A. Vigouroux, ENSA, Bugwood.org 


\section{CONTRIBUTING FACTORS}

This disease is primarily spread in the landscape via contaminated tools, such as pruning blades and brushes used to apply wound dressings. Exposed tissues, including phloem, cambium, and sapwood, can be quickly invaded. Although less important, some insects, especially beetles in the family Nitidulidae, naturally spread spores between trees because they are attracted to tree wounds and fruity odors emitted by the canker stain fungus.

\section{MANAGEMENT RECOMMENDATIONS}

Once a tree is infected, nothing can be done to save it. Infected trees must be removed from the site and destroyed, preferably by burning, to reduce local spread of the disease, which can persist for several years in dead wood. Proper cultural management and strict sanitation procedures are paramount. Young trees should always be inspected before leaving the nursery and at planting. All equipment must be sanitized between trees during maintenance using near-boiling water, soap, or a bleach solution. When limb pruning is necessary, doing so in midwinter, when fungal activity is lowest, will minimize infection of pruning wounds, whereas exposed pruning wounds during the summer months are most likely to become infected.

\section{Sycamore Anthracnose (Apiognomonia veneta) \\ SPECIES SUSCEPTIBILITY}

American sycamore is highly susceptible to sycamore anthracnose, whereas Oriental planetree shows resistance, a valuable trait apparently passed on to some of the London planetree hybrids. London planetree 'Bloodgood' may offer better resistance than 'Liberty'; other selections, such as 'Columbia' and 'Yardwood', have also demonstrated good resistance, but susceptibility varies. A selection of the Western sycamore (Platanus racemosa 'Roberts') is known for resistance to anthracnose, although this species is not typically grown outside its native range in California.

\section{RECOGNITION}

Sycamore anthracnose can cause visible symptoms such as cankers on twigs and stems, while the leaves take on a spotted or blotched appearance primarily along the midrib. The most common symptom is delayed regrowth of leaves in the spring.

\section{CONTRIBUTING FACTORS}

Wet spring weather facilitates the growth and dispersal of fungal spores to new growth shoots and leaves.

\section{MANAGEMENT RECOMMENDATIONS}

Because most trees will recover from sycamore anthracnose infection after drying out in warmer weather, thinning the canopy to increase airflow and provide more access to sunlight can reduce the severity of the pathogen by allowing the tree canopy to dry out more quickly after rainstorms. Additionally, pruning infected branches and removing fallen leaves may reduce the presence of the anthracnose and thus reduce the chance of it spreading. Chemical control is possible, but not usually encouraged, and may include preventive applications or postinfection applications of a fungicide.

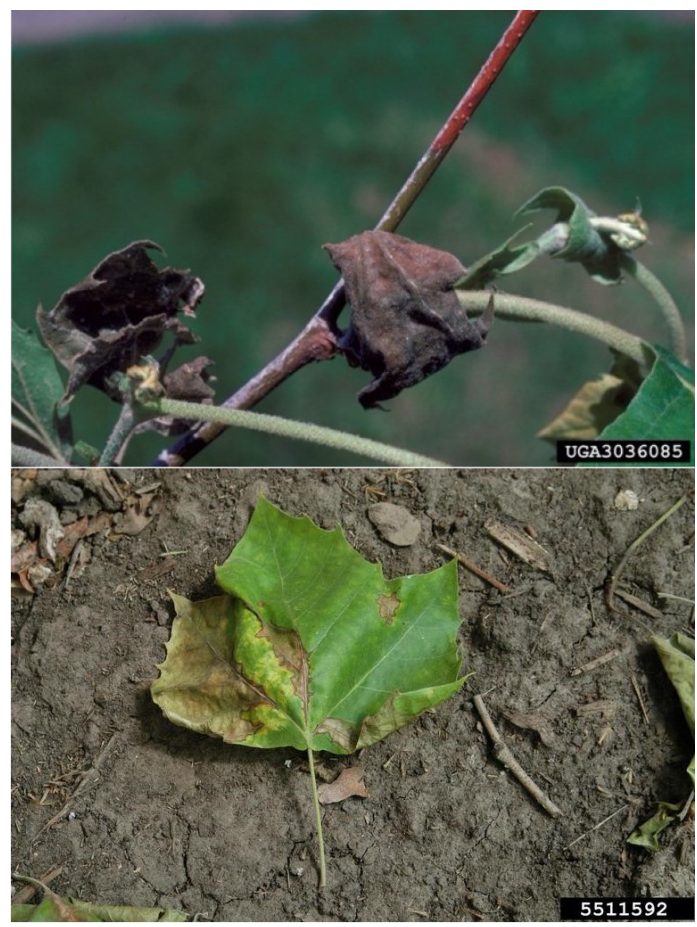

Figure 8. Symptoms of sycamore anthracnose on leaves and twig. Credits: (Top) Robert L. Anderson, USDA Forest Service; (Bottom) Ward Upham, Kansas State University, Bugwood.org

\section{References}

Engelbrecht, C. J., and T. C. Harrington. 2005. "Intersterility, Morphology and Taxonomy of Ceratocystis fimbriata on Sweet Potato, Cacao and Sycamore." Mycologia 97 (1): $57-69$.

Gilman, E. F., D. G. Watson, R. W. Klein, A. K. Koeser, D. R. Hilber, and D. C. McLean. 2018. "Platanus occidentalis: Sycamore.” EDIS 1993 (6). https://edis.ifas.ufl.edu/st484

Halbert, S. E., and J. R. Meeker. 2017. "Sycamore Lace Bug, Corythucha ciliata (Say) (Insecta: Hemiptera: Tingidae)." EDIS 2004 (4). https://edis.ifas.ufl.edu/in347 
Knox, G. W. 2020. “Rzedowski’s Sycamore (Platanus

rzedowskii), a Smaller Alternative to American Sycamore."

EDIS 2014 (3). https://edis.ifas.ufl.edu/ep502

Knox, G. W., and D. G. Watson. 2014a. "Platanus orientalis var. digitata: Cut-Leaf Oriental Planetree.” https://edis.ifas. ufl.edu/st486

Knox, G. W., and D. G. Watson. 2014b. "Platanus x acerifolia 'Bloodgood': 'Bloodgood' London Planetree." EDIS 1993 (6). https://edis.ifas.ufl.edu/st487

Knox, G. W., and D. G. Watson. 2014c. "Platanus x acerifolia 'Liberty': 'Liberty' London Planetree." EDIS 1993 (6). https://edis.ifas.ufl.edu/st488

Mizell, R. F., P. C. Andersen, C. Tipping, and B. V. Brodbeck. 2015. "Xylella fastidiosa Diseases and Their Leafhopper Vectors.” EDIS 2004 (1). https://doi.org/10.32473/ edis-in174-2003

Partyka, R. E., J. W. Rimelspach, B. G. Joyner, and S. A. Carver. 1980. Woody Ornamentals. 1st Ed., p 318. Columbus, $\mathrm{OH}$ : ChemLawn Corporation.

Sinclair, W. A., and H. H. Lyon. 2005. Diseases of Trees and Shrubs. No. Ed. 2. Comstock Publishing Associates.

UF/IFAS. 2015. “Powdery Mildew.” 4-H Forest Resources. http://sfrc.ufl.edu/extension/4h/foresthealth/diseases/ powdmild.html 